\title{
A RECEPÇÃO DAS INVESTIGAÇÕES LÓGICAS POR PAUL NATORP *
}

\section{Carlos Morujão}

Universidade Católica Portuguesa

As Investigaçães Lógicas, nas suas duas partes, que se repartem por três volumes e mais de 900 páginas, publicadas em 1900-01, mas remontando a lições de Husserl, em Halle-an-der Saale, de meados da última década do século XIX, são, em larga medida, uma obra de polémica. Em primeiro lugar, nos Prolegómenos a uma Lógica Pura, e como é amplamente conhecido, com o psicologismo, mas também, sobretudo nos dois volumes seguintes, as "Investigações para a Fenomenologia e a Teoria do Conhecimento", com diversos representantes da escola de Brentano e com o próprio Brentano, em torno de questões tão diversas como a doutrina da intencionalidade, a doutrina da relação entre o todo e as partes, ou o problema das significações dependentes e independentes. A polémica com o neokantismo é menos perceptível, se exceptuarmos os $\S \S$ dos Prolegómenos dedicados, por Husserl, à refutação do psicologismo de diversos representantes da escola, pertencentes à geração que o precedera, o que, em si mesmo, reconheçamo-lo, não representava já grande novidade; como veremos, críticas muito semelhantes tinham já sido feitas, entre outros, por Paul Natorp, de quem nos ocuparemos neste ensaio. Contudo, um debate com o próprio Natorp é claramente perceptível em diversas páginas da $5{ }^{a}$ Investigação.

O nosso propósito, neste ènsaio, não é proceder a uma análise exaustiva das relações entre Husserl e Paul Natorp, nem, muito menos, a uma análise global das relações entre a fenomenologia e o neo-kantismo. Limitamo-nos, como dizemos no título, à leitura que foi feita, por Paul Natorp, da 1. a edição

* Uma primeira versão deste texto foi lida por nós no Colóquio Internacional "Husserl e suas Investigações Lógicas", organizado pelo Projecto de Investigação "Tradução de Husseri", do Centro de Filosofia da Universidade de Lisboa, e Programa de Pós-graduação em Filosofia da Universidade Federal do Rio de Janeiro, a 8 e 9 de Maio de 2008. 
das Investigações Lógicas, tanto na sua recensão dos Prolegómenos a uma Lógica Pura, publicada em 1901 nos Kant-Studien, como, em 1912, na Allgemeine Psychologie nach kritischer Methode. Como, porém, as Investigações Lógicas reenviam, frequentemente, para a Einleitung in die Psychologie, de Natorp, publicada em 1888 (que se inscreve, por isso, num horizonte temporal muito próximo do que rodeou a redacção desta obra seminal de Husserl), será a partir dos temas natorpianos que encontram uma sua primeira expressão nesta obra que estabeleceremos um confronto entre o pensamento dos nossos dois filósofos. Teremos ainda em consideração o ensaio de Natorp de 1887 intitulado "Fundamentação Subjectiva e Objectiva do Conhecimento", para o qual o seu autor remete em diversas ocasiões, tanto na recensão que mencionámos, como na Einleitung. Começaremos, então, fazendo o "ponto da situação", baseando-nos, como é compreensível, em trabalho que já outros realizaram antes de nós. ${ }^{1}$ Recorde-se que se trata de um diálogo entre os dois pensadores que, para além da expressão pública que teve nas obras por eles publicadas, se prolongou na vasta correspondência entre ambos. A nossa primeira tarefa deverá ser, por isso, localizar, nas respectivas obras, os momentos em que o confronto se deu. Os elementos a ter em conta para a abordagem desta questão são os seguintes:

1. A recensão, já mencionada, dos Prolegómenos, por Paul Natorp, publicada em 1901 no n. ${ }^{\circ} 6$ dos Kant-Studien, intitulada "Zur Frage der logischen Methode".

2. As diversas referências de Husserl, na 1.a edição das Investigações Lógicas, à 1. a edição da Einleitung in die Psychologie de Paul Natorp.

3. As reacções de Natorp a elas, na Allgemeine Psychologie, bem como algumas referências a essas mesmas reacções, por parte de Husserl, na 2. ${ }^{a}$ edição, de 1913, das Investigações Lógicas.

4. A referência de Natorp, na Allgemeine Psychologie, ao que chama a "nova posição" de Husserl em Philosophie als strenge Wissenschaft, com as suas alterações às posições defendidas na obra de 1900-01.

5. Algumas referências esparsas, do ano de 1913, a Paul Natorp, nas Ideias para uma Fenomenologia Pura e uma Filosofia Fenomenológica.

6. Referências esparsas às Investigações Lógicas, quase sempre em sinal de concordância e, muitas vezes, em simples nota de rodapé, na Sozialpedagogik de Natorp. ${ }^{2}$

1 Cf. Iso Kern, Husserl und Kant, Den Haag, Martinus Nijhoff, 1964, pp. 321 e segs.

2 Paul Natorp, Sozialpedagögik, Paderborn, Ferdinand Schöningh, 1974; cf., nomeadamente, todo o $\$ 4$ (pp. 35 e segs.) e o contraste que aí é estabelecido entre a crítica do conhecimento e a psicologia. 
Será ao comentário das passagens de ambos os autores que são mencionadas nos pontos 2 e 3 que dedicaremos a maior parte das páginas que se seguem. Só acerca delas pretendemos oferecer ao leitor um comentário que seja tanto quanto possível exaustivo e que nos possa servir como uma espécie de ponto de apoio para uma futura abordagem completa das relações entre Husserl e Natorp.

\section{A recensão dos Prolegómenos por Paul Natorp}

Para Natorp, a recensão dos Prolegómenos constituirá, em primeiro lugar, uma ocasião para clarificar a sua própria posição sobre a relação entre o plano da lógica e o da sua realização em actos psíquicos concretos, e, em segundo lugar, para determinar as relações entre a lógica como ciência demonstrativa e independente da psicologia, e como ciência puramente teórica da verdade objectiva. A uma observação de Husserl, nos Prolegómenos, segundo a qual a filosofia transcendental de Kant permanece no âmbito de uma investigação sobre as faculdades da alma, enquanto fontes do conhecimento, e, por conseguinte, prisioneira do psicologismo, Natorp responde ${ }^{3}$ que tal se poderia eventualmente dizer da recondução, feita por F. A. Lange, do a priori kantiano ao plano da organização psicofísica, mas não das teorias de Hermann Cohen e da sua escola. Ora estes últimos, por sua vez, mais não fizeram do que seguir a indicação, já incluída na Crítica da Razão Pura, de que qualquer proposição sintética não pode ser tida por imediatamente certa sem uma prévia dedução da sua pretensão a exprimir uma verdade, ou seja, sem se demonstrar a possibilidade de ela se referir à forma de uma experiência em geral.

Natorp tem em vista, como é óbvio, a quase exclusiva referência à tese de Lange, nos Logische Studien, que é feita no $§ 28$ dos Prolegómenos. ${ }^{4}$ Aí, apoiando-se na afirmação de Lange, segundo a qual a matemática e a lógica encontram os seus fundamentos na nossa intuição do espaço, Husserl denunciara como psicologismo, mesmo se transcendental, as doutrinas dos principais seguidores de Kant (e em parte também as do próprio Kant) sobre este assunto. O mesmo psicologismo é ainda denunciado por Husserl na jus-

3 Cf. Idem, "Zur Frage der logischen Methode", in Kant-Studien, 6 (1901) 270-283, agora in Hermann Noack (hrsg.), Husserl, Darmstadt, Wissenschaftliche Buchgeselschaft, 1973, pp. 1-15, pp. 11-12.

4 No § 28 dos Prolegómenos, Husserl menciona ainda Karl Kroman e Otto Liebmann como seguidores de Lange. Poder-se-ia mencionar ainda, entre vários outros representantes da mesma tendência, Helmholz ou Hermann Zeller. A feição qúe o neokantismo tomou entre estes representantes da sua primeira geração ficou a dever-se, entre outros factores, aos desenvolvimentos contemporâneos da psicofisiologia. Com efeito, a tendência, comum a todos eles, em reinterpretar as formas a priori de Kant no sentido de propriedades inatas da mente - tendo como efeito uma redução do plano transcendental kantiano a uma característica particular do psiquismo humano - colocava a validade objectiva do conhecimento na dependência de um acto subjectivo e, em última instância, contingente. 
tificação que Lange apresenta da validade do princípio de não contradição (considerado, além disso, como o ponto em que as leis naturais do pensar se encontram com os princípios normativos), enquanto mero resultado da impossibilidade em combinar, no pensamento, dois conteúdos postos como contraditórios entre si. Uma tal impossibilidade, apesar de real, seria em si mesma, para Husserl, destituída de valor se não exprimisse uma impossibilidade de direito, quer dizer, a incompatibilidade entre duas significações contraditórias. Ora, a tese de Hussel, a que Natorp dá também o seu assentimento, é a de que, se aquela primeira impossibilidade fosse apenas o resultado desta última incompatibilidade - quer dizer, se entre a segunda e a primeira subsistisse uma relação de tipo causal -, seria legítimo perguntar ainda pela razão da incompatibilidade..$^{5}$ A tese psicologista, dirá mais tarde Natorp na Sozialpedagögik, parece assentar numa confusão entre o que é um acontecimento e o que é um facto. ${ }^{6} \mathrm{Na}$ realidade, se os identificarmos, nada impede que consideremos $2 \times 2=4$, por exemplo, como um facto, para o qual haveria que buscar a necessária explicação de ordem causal. Mas, se restringirmos as explicações de ordem causal àquilo que acontece no tempo e se só a isso chamarmos um facto, então, a explicação da validade daquela operação aritmética não será já de natureza causal.

Mas quem quiser, ainda assim, encontrar o psicologismo, encontrá-lo-á em qualquer parte, diz, na sua recensão, Natorp com alguma ironia, até mesmo, provavelmente, em Husserl. No que diz respeito a Kant e à sua escola, dever-se-á ter em atenção que termos como "entendimento" ou "razão" não constituem instâncias de carácter psicológico, nas quais se buscaria a solução para os problemas do conhecimento; eles indicam apenas o facto de o conteúdo objectivo do conhecimento ter ainda de se apresentar no decurso subjectivo do acto de conhecer, tal como - continua Natorp - o próprio Husserl não pode senão conceder que o "ideal" se realiza em instâncias psíquicas concretas. Mas relativamente às questões fundamentais, Natorp, nesta recensão, expressa o seu acordo com Husserl, nomeadamente, quanto ao facto de a questão lógica fundamental ser a da fundamentação da possibilidade efectiva das ciências existentes. ${ }^{7} \mathrm{O}$ filósofo de Marburg observa, apenas, que este programa fora

${ }^{5}$ Cf. Natorp, "Zur Frage der logischen Methode", p. 3. Duvidamos que Husserl concordasse, pelo menos em 1901, com o modo como Natorp formula a tese husserliana de uma independência entre o âmbito da psicologia e o da lógica. Na realidade, Natorp diz que a impossibilidade psicológica remete para o plano da experiência, enquanto a incompatibilidade lógica remete para o plano da legitimidade da experiência, o que, expresso em termos kantianos, significaria: todo o nosso conhecimento começa pela experiência, mas nem todo resulta, por isso, dela.

${ }^{6}$ Idem, Sozialpedagögik, ed. cit., p. 37.

${ }^{7}$ Como é óbvio, Natorp refere-se ao Husserl das Investigações Lógicas. Duvidamos que Husserl, após ter efectuado, no $\S 60$ de Ideias I (Hua, Band III, p. 143), uma distinção entre essências imanentes e essências transcendentes, pudesse concordar ainda com Paul Natorp. Noções como as de "coisa", "figura espacial", "movimento", "cor", etc., constituirão, para Husserl, princípios cuja validade deverá ser determinada pelas ontologias regionais (nomea- 
já o de Kant, cujo principal contributo para os estudos lógicos se deverá procurar, não nas lições de lógica publicadas postumamente por Jäsche, mas sim na Lógica Transcendental da Crítica da Razão Pura. ${ }^{8}$ Relativamente à necessidade de afastar o psicologismo de qualquer programa de fundamentação da lógica, Natorp afirma que Husserl e ele próprio não poderiam estar senão de acordo. Natorp pode, por isso, na referida recensão, mencionar todos os seus trabalhos nesse sentido, desde o já mencionado ensaio de 1887 intitulado "Sobre a fundamentação objectiva e a fundamentação subjectiva do conhecimento". ${ }^{9}$ Com efeito, Natorp defendera que uma ciência geral do conhecimento, como é o caso da lógica, não se pode apoiar nos resultados de uma ciência particular, como é a psicologia (cujas proposições verdadeiras são-no apenas de acordo com as suas próprias leis particulares); por outras palavras, a determinação do critério de verdade para todos os domínios do conhecimento não pode depender de uma ciência cujas verdades supõem já a validade universal do referido critério. Na verdade, em 1887, Natorp não pensa estar a defender, contra o psicologismo, unicamente, a validade objectiva das proposições lógicas, mas igualmente a de todas as proposições da ciência, uma vez que, para esta, a conexão dos conhecimentos é determinada por uma estrutura legal cuja fundamentação não pode ser de ordem subjectiva. No ensaio que acabámos de citar, Natorp afirma:

É [...] certo que a consciência da verdade, em ciências do género das matemáticas ou das ciências matemáticas da natureza (para nos limitarmos às ciências que podem fazer valer a fundação mais rigorosa das suas proposições), é independente da compreensão das forças ou das funções graças às quais essa verdade, do ponto de vista da sua possibilidade objectiva, se torna inteligível como propriedade da psyché. ${ }^{10}$

No combate de Husserl contra o psicologismo, Natorp não poderia senão ver, por isso - e com inteira razão, convém reconhecê-lo -, uma repetição do

damente pela ontologia da região "mundo físico"), caindo fora do âmbito da fenomenologia enquanto ciência descritiva das essências imanentes. Cf. a passagem seguinte: "Assim, pois, tal como desconectamos a natureza física real e as ciências naturais empíricas, desconectamos também as ciências eidéticas, isto é, as que estudam, de um ponto de vista ontológico, o que é essencialmente inerente aos objectos da natureza física enquanto tais."

8 Paul Natorp, ibidem, ed. cit., pp. 12-13.

9 Idem, "Über objektive und subjektive Begründung der Erkenntnis", in Philosophische Monatshefte, XXIII (1887) 139-168; cf., nomeadamente, a seguinte passagem da p. 147: "Afirmando que a validade objectiva deve ser fundada objectivamente, não pensamos estar a defender apenas os direitos da lógica, de acordo com o conceito admitido até aos nossos dias, mas pensamos defender a pretensão, que qualquer ciência reclama, à validade objectiva da sua verdade." Na Allgemeine Psychologie nach kritischer Methode, Tübingen, J. C. B. Mohr (Paul Siebeck), 1912, reimp., Amsterdam, E. J. Bonset, 1965, p. 280. Natorp volta a mencionar o seu acordo com Husserl sobre este assunto, reenviando, quer para o ensaio de 1887, quer para a Sozialpedagogik. Idem, ibidem, p. 148. 
seu próprio combate (bem como o de Hermann Cohen), na década de 80 do século XIX, contra o psicologismo da geração neo-kantiana que o precedera. ${ }^{11}$ Esta primeira geração neo-kantiana, a de 1850 a 1870, grosso modo, era, justamente, um dos alvos do ataque de Husserl na obra de 1900, onde, por outro lado, a marca deixada pela leitura das obras de Natorp (com as quais Husserl entra em contacto pelo menos desde 1894) é considerável. Todavia, Natorp admite que uma questão possa não ter sido ainda totalmente clarificada nos Prolegómenos, a saber, a da relação entre o lógico e o psíquico, entre o ideal e o real, se é que este último não está destinado, para Husserl, a permanecer como um simples "resto" de que o primeiro não saberia dar conta, ${ }^{12}$ ou se é que a ligação entre o valor lógico intemporal e a factualidade temporal das vivências psíquicas não está condenada a permanecer envolta num enigma impenetrável. Por outras palavras, à "realização do ideal" deverá ser também possível conceder algum significado do ponto de vista lógico. ${ }^{13}$ Ao pôr em evidência a relação entre o "formal" em sentido husserliano, quer dizer, o "puro" e "objectivo", e o "transcendental" no sentido de Kant, Natorp é muito claro quanto a este ponto:

Mas em Husserl permanece também por resolver a oposição entre o formal e o material, o apriórico e o empírico, com isso, também, entre o lógico e o psicológico, o objectivo e o subjectivo; ou, para o dizer numa única expressão e, simultaneamente, na sua própria terminologia, entre o ideal e o real. ${ }^{14}$.

Por outras palavras, a ausência de um questionamento, por parte de Husserl, sobre a natureza da ligação lógica entre o plano formal e o plano material traduz-se na brusca separação entre os dois. Mas esta questão, contudo, remete-nos para o problema da acusação de uma "recaída" de Husserl no psicologismo, ou numa certa forma de psicologismo, no $2 .^{\circ}$ Tomo das Investigações

11 Já em 1907 Ernst Cassirer chamara a atenção para a semelhança das posições de Natorp e de Husserl quanto a este assunto. Cf. Das Erkenntnisproblem in der Philosophie und Wissenschaft der neueren Zeit, trad. cast., vol. II, p. 527, nota 19.

12 Esta questão é mencionada na carta de Husserl a Natorp, de 07.09.1901, in Edmund Husserl, Logische Untersuchungen, Ergänzungsband, Erster Teil, Husserliana, Band XX/1, Dordrecht / Boston / Lancaster, Kluwer Academic Publishers, 2002, p. 400.

13 Natorp, "Zur Frage der logischen Methode”, p. 14. Jocelyn Benoit, Phénoménologie, Sémantique, Ontologie, Paris, PUF, 1997, p. 233, menciona este problema, mas não nos parece que tenha entendido a posição de Natorp. O enigma a que fazemos referência no texto, e a que Benoit faz igualmente referência no seu comentário, foi, para Natorp, inteiramente resolvido pela escola neo-kantiana de Marburg (se é que não o fora já pelo próprio Kant) e subsiste apenas em Husserl em virtude da indeterminação em que as Investigações deixam a caracterização do modo-de-ser do psíquico. (Veja-se, a este propósito, o que dizemos mais abaixo na nota n. ${ }^{\circ}$ 15.) Que, por outro lado, se trata aqui da questão da determinação ontológica do nível próprio da experiência fenomenológica, é bem evidenciado pelo autor. (Cf. p. 232.)

${ }^{14}$ Cf. Natorp, "Zur Frage der logischen Methode", p. 13. 
Lógicas, de que falaremos adiante. ${ }^{15}$ Note-se que Natorp chama psicológicas às seis investigações que Husserl caracteriza, justamente, como fenomenológicas. Na linguagem de Natorp, tal quer dizer que a Segunda Parte das Investigações se dedica à tarefa da fundação subjectiva do conhecimento, em forte contraste com a defesa se uma fundação objectiva da lógica e do conhecimento em geral, proclamada na Primeira Parte, ou seja, nos Prolegómenos. Adiantemos, somente, que a mencionada acusação de recaída no psicologismo significa apenas, para Natorp, que Husserl não teria esclarecido com suficiente clareza a natureza do psiquismo. As insuficiências de Husserl seriam patentes, na opinião de Natorp, no facto de reclamar para a fenomenologia um procedimento puramente descritivo, como se este procedimento não devesse já pressupor uma certa ideia - ou seja, uma teoria - da natureza daquilo que há que descrever.

\section{As referências de Husserl a Paul Natorp, das Investigações Lógicas a Ideias I}

Se prestarmos atenção à 2. ${ }^{a}$ Parte das Investigações Lógicas, ou seja, às seis investigações propriamente ditas, verificamos que as referências a Natorp são escassas, cerca de uma meia dúzia, e, com excepção da última, todas elas feitas na $5 .{ }^{\text {a }}$ Investigação. ${ }^{16}$ Procederemos, de seguida, a uma análise de cada uma delas individualmente.

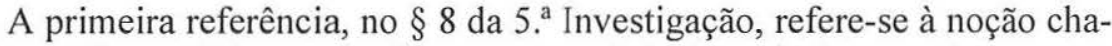
mada por Natorp "Bewusstheit", consciencialidade, quer dizer, a relação entre um qualquer conteúdo da consciência e o Eu enquanto centro de referência subjectivo de qualquer conteúdo ("ein Bezugspunkt", como lhe chama o texto alemão da Allgemeine Psychologie). A consciencialidade, como Natorp explicará na obra de 1912, é um dos três momentos ou aspectos que podemos distinguir na noção de consciência, sendo os outros dois, primeiro, o conteúdo, ou seja, aquilo de que se é consciente, ou de que existe consciência (como diz Natorp, aquilo que pode surgir para a consciência como um genitivo objectivo); e, em segundo lugar, o que em filosofia, habitualmente, se chama o Eu ou o sujeito: por outras palavras, aquele para quem um tal conteúdo é consciente, e. não uma substância ou um suporte permanente de qualidades ou modos. ${ }^{17}$ Ora Husserl contesta, na passagem que mencionámos, a tese de Natorp segundo a qual a consciencialidade deva ser considerada como um facto primitivo que nunca se pode tornar objecto. A tese de Natorp, contudo, é clara: a relação entre aquilo de que existe consciência e a própria consciência

15 Idem, Allgemeine Psychologie, p. 280.

16 As referências, nos volumes XIX/1 e XIX/2 da Husserliana, encontram-se nas páginas 372-373, 376, 393-394, 400 e 883.

17 Paul Natorp, Allgemeine Psychologie, ed. cit., pp. 24-26. 
para a qual isso existe não é um facto da consciência, mas sim um elemento último e irredutível, que não é susceptível de esclarecimento posterior. ${ }^{18}$

Mas Husserl argumenta que, se aquele Eu se torna visível por meio de uma diferenciação relativamente aos conteúdos objectivos da consciência, como o próprio Natorp admite, então, a consciencialidade torna-se objectiva, num sentido lato do termo, e susceptível de análise. (A importância desta afirmação vê-la-emos de aqui a pouco.) Convém, no entanto, prestar atenção ao seguimento do texto da $5 .{ }^{a}$ Investigação. ${ }^{19} \mathrm{~A}$ tese defendida por Natorp, diz Husserl, é insustentável na sua formulação, simplesmente porque Natorp retira uma conclusão falsa das suas próprias premissas; ou seja, admite a existência de um Eu puro, embora conclua que dele nada se pode saber. Provavelmente, como Natorp reconhecerá em 1912 os dois autores não estarão a falar exactamente do mesmo. ${ }^{20}$ Enquanto Husserl defende que o facto de algo ser objecto para um Eu (e é nisto que consiste a Bewusstheit) se poderá transformar ele próprio em objecto de um acto subsequente (embora aparecendo neste segundo acto como unidade meramente empírica ou psicológica), Natorp defende que tal nunca poderá acontecer no interior de um mesmo acto. Veja-se, por exemplo, o que diz Husserl no $\S 8$ da 5. ${ }^{a}$ Investigação:

Do mesmo modo que o volver-se da atenção para um pensamento, para uma sensação, para um sentimento de mal-estar, etc., torna essas vivências objecto de percepção interna, sem que, com isso, os torne objectos no sentido de coisas, igualmente esse Eu centro de referência e essa relação determinada do Eu com os conteúdos seria, enquanto expressamente notada, também objectivamente dada. ${ }^{21}$

Em 1901, é a própria existência deste Eu, chamado "centro de referência", que Husserl põe em dúvida, afirmando que, fenomenologicamente, a única coisa que estamos em condições de notar é o eu empírico, na relação empírica que mantém com as suas próprias vivências. Este último eu mais não é do que um dado entre outros, nesse âmbito metafisicamente neutro - ou tido

18 Idem, ibidem, p. 27. Seria interessante verificar se, em Ideias I, por exemplo, no $\S 80$, Husserl não retoma precisamente esta linguagem para caracterizar o Eu puro. Sendo as vivências passíveis de descrição, bem como o modo como são experimentadas, já não o é, contudo, defende Husserl, o próprio Eu que as experimenta, mesmo encontrando-se entretecido com cada uma delas. A orientação subjectiva da descrição fenomenológica não visa, por conseguinte, um Eu existente por si, mas apenas um Eu que constitui a objectividade. Atente-se, por exemplo, na passagem seguinte (Hua, Band III, p. 195): "Neste peculiar estar entrelaçado com todas as suas "vivências", o Eu que experimenta não é, todavia, nada que por si possa ser tomado e transformado em objecto de uma investigação peculiar. Prescindindo dos seus "modos de relação" ou "modos de comportamento", ele não possui qualquer conteúdo explicável, é, em e por si mesmo, impossível de descrever: puro Eu e nada mais."

19 Husserl, ibidem, p. 374.

20 Cf. Paul Natorp, Allgemeine Psychologie nach kritischer Methode, ed. cit., p. 34. 
por tal, pelo menos - que é para Husserl, em 1901 a psique. Âmbito neutro, dissemo-lo, na medida em que a psique não é um sujeito real que tenha diante de si um mundo igualmente real; ela constitui, antes, o lugar onde tal distinção se pode fazer - em termos que Husserl admite que possam ter o carácter, tanto de teses idealistas, como de teses realistas -, enquanto mais não é do que um mero complexo de vivências para o qual o mundo constitui, apenas, o objecto intencional. Repare-se ainda naquele "seria" (wäre, no original alemão) da citação que acabámos de fazer, que exprime com nitidez todas as dúvidas de Husserl relativamente a este assunto. O equívoco de Natorp, para Husserl, está, em primeiro lugar, no facto de admitir a necessidade de um Eu puro; só secundariamente, porque o admite e simultaneamente defende que dele nada se poderá dizer senão tautologicamente, é que a sua posição encerra uma contradição. (Por outras palavras: admitir este Eu, como faz Natorp, não encerra, segundo Husserl, qualquer contradição; releva, simplesmente, de uma decisão de carácter metafísico que as Investigações Lógicas se recusam a tomar. ${ }^{22}$ ) Se um tal Eu, como diz Husserl repetindo Natorp, constitui o "facto fundamental da psicologia", é porque, de algum modo, o pensamos e o tornamos objecto, ou seja, o consideramos como tema de verificação. As reservas de Natorp quanto à possibilidade de fazermos uma experiência dele não são, por isso, do ponto de vista husserliano nas Investigações Lógicas, justificadas. Simplesmente, nestas condições, a psicologia não poderia ser aquilo que dela esperava Natorp: estaria condenada a permanecer, segundo Husserl, para sempre uma ciência empírica, correspondendo ao carácter empírico do próprio eu que ela toma por objecto. Mas é por este motivo, porque relativamente a esta questão haverá, entre a 1 a $^{\mathrm{a}}$ e a 2 . $^{\mathrm{a}}$ edições das Investigações Lógicas, uma alteração na posição de Husserl, que é extremamente importante percebermos o alcance da segurda referência explícita a Natorp na obra de 1901.

Esta segunda referência, no aditamento acrescentado na 2. ${ }^{a}$ edição da obra ao $\S 8$, começa por mencionar o facto de Husserl não ter modificado a parte final deste parágrafo - apesar de já não concordar com o que aí defendera em 1901 -, uma vez que Paul Natorp se referira criticamente a ele na 2. ${ }^{a}$ edição, de 1912, da Einleitung in die Psychologie nach kritischer Methode. ${ }^{23}$ Trata-se de uma passagem decisiva da 5 . $^{\mathrm{a}}$ Investigação, não menos decisiva do que a alteração da posição de Husserl, no tempo que mediou entre a $1 .^{\mathrm{a}}$ e a $2 .^{\mathrm{a}}$ edições; falaremos dela também mais adiante, quando mencionarmos a crítica de Natorp a Husserl. Este aditamento deverá ser lido em relação com todo o $§ 57$ de Ideias $I$ e a nota que o acompanha. (Husserl reenviara já, anteriormente, para este parágrafo das Ideias, numa nota acrescentada na $2{ }^{\text {a }}$ edição das Investigações Lógicas, que se pode ler na p. 364 do volume XIX/1 da

22 Cf. Jocelyn Benoît, Phénoménologie, Sémantique, Ontologie, ed. cit, p. 280.

23 Trata-se, na realidade, da Allgemeine Psychologie nach kritischer Methode, que não constitui propriamente uma 2 . $^{a}$ edição da obra de 1888 , mas antes uma profunda reelaboração do conjunto das problemáticas nela abordadas. 
Husserliana. ${ }^{24}$ ) Na obra de 1913, depois de ter afirmado, como dissemos na nota anterior, que a corrente das vivências se tem de converter em cogitationes actuais - ou, exprimindo esta ideia na linguagem de Kant: que "o eụ penso deve poder acompanhar todas as minhas representações", tese que recusara em 1901 -, Husserl afirma que defendeu, nas Investigações Lógicas, um cepticismo relativamente à questão do Eu puro que o progresso das suas investigações já lhe não permite manter. Acrescenta, então, que as críticas que dirigiu, na obra de 1901, à Einleitung in die Psychologie de Natorp não eram justas relativamente ao que designa como "um ponto central".

Tentemos ver do que se trata. O ponto central de que fala Husserl, ao que julgamos, é o que diz respeito à passagem do que poderíamos chamar, na linguagem de David Hume, "a bundle of sensations" - unidade sem função unificante de um conjunto de sensações -, ao Eu capaz de as unificar. Parece óbvio que, por exemplo, a representação de uma sucessão de fenómenos no tempo não se confunde com uma mera sucessão de representações, no interior da qual a cada uma delas corresponderia um fenómeno particular; pensamos, com o princípio de causalidade, em algo mais do que na sucessão de modificações, ou diferenças de estado, em dois corpos, em momentos distintos do tempo. A representação de uma sucessão não está sujeita ao mesmo fluir temporal que a própria sucessão, supondo, por isso, um Eu imóvel, a que se poderia chamar o centro de uma periferia de curvatura variável, ${ }^{25}$ conforme a natureza dos diversos actos de enlace, de conteúdo sempre diverso. A este Eu não corresponde, por certo, nenhum conteúdo fenomenológico específico, uma vez que ele não se identifica com a unidade de relação presente em cada acto particular de síntese; ele exprime, apenas, a unidade (fora do espaço e do tempo) de uma legalidade que possibilita que tais actos se efectuem. E embora esta legalidade, segundo Natorp, encontre apenas uma expressão abstracta na experiência imediata, ela é, no entanto, o que existe de mais concreto, na medida em que se manifesta como ideia de unidade, ou exigência de concreção. Em 1912, Natorp falará do carácter ilimitado (grenzenloss) e persistente (beharrend), de um tal Eu, chamando-lhe ainda o fundamento dos aparecimentos, no mesmo sentido em que o termo fundamento pode ser dito das ideias de Platão. ${ }^{26}$

24 A argumentação husserliana, nesta passagem de Ideias I, consiste em dizer que todas as vivências têm de pertencer a uma única corrente de vivências, que é a minha, devendo converter-se em cogitationes actuais e tornar-se imanentes nelas. É este Eu, resultado da desconexão fenomenológica do mundo, que Husserl caracteriza, de acordo com a definição bem conhecida, como "resíduo" e, uma vez que transcende todas as vivências que acompanha (não se situando, em todo o caso, para lá delas), como uma "transcendência na imanência". (Cf. Hua, Band III, pp. 137-138.)

A expressão krümmung der Peripherie encontra-se na Allgemeine Psychologie, ed. cit., p. 37.

26 Paul Natorp, Allgemeine Psychologie, ed. cit. p. 39. Assim como a ideia de Platão se encontra para com o sensível a que serve de modelo, assim também o aparecer, de acordo com uma legalidade, se encontra para com cada aparecimento. O aparecer, como é óbvio, não aparece, tal como a ideia, enquanto modelo, não tem, ela própria, um modelo. Cf., igualmente, ibidem, p. 36. 
Mas se interpretássemos este Eu, como afirmava Natorp em 1888, como uma substância a que tivéssemos acesso por abstracção relativamente a todos os conteúdos determinados da consciência, ele mais não seria do que um "qualquer coisa inexplicável" e vazio, ${ }^{27}$ ou seja, o conceito de alguma coisa que seria incapaz de conceber efectivamente fosse o que fosse e, por conseguinte, inútil. A crítica humeana a um tal conceito seria, neste caso, plenamente justificada. Mas, segundo Natorp, o Eu exprime apenas a unidade do processo de constituição do objecto - o que dá ao conhecimento a sua fundamentação objectiva -, o facto de a multiplicidade sensível ser reconduzida a uma instância em que aparece sob a forma de unidade de uma multiplicidade, de acordo com uma legalidade determinada. A representação de uma sucessão, por exemplo, é um acto particular de síntese, no qual nenhum dos elementos constituintes pode ser isolado ou abstraído sem que, com isso, se dissolvesse o que é específico de uma tal representação. ${ }^{28}$ Em 1912, Natorp lembrará a Husserl a necessidade de distinguir os conteúdos ligados (por um Eu, obviamente), dos próprios conteúdos, mesmo que considerados na sua ligação, ou seja, de distinguir o múltiplo a unificar da unidade de uma multiplicidade. ${ }^{29}$ Ou seja: não sou apenas consciente de um certo "a", de um certo "b", de um certo "c", etc., mas sim de $(a, b, c)$ enquanto momentos de um objecto "S". Isto significa que não ligo "a" a "b", este, por sua vez, a "c", etc., de modo que "S" surja como resultado de uma tal ligação; antes ligo $(a, b, c)$ em "S" e remeto a ligação a que procedo entre eles à operação que constitui aquele objecto como um "S $(\mathrm{a}, \mathrm{b}, \mathrm{c})$ ". Surge, neste momento, a necessidade de pensar a Bewusstheit: que não é nem uma pura diversidade sem unidade, nem uma mera unidade unificada de conteúdos diversos tomados em conjunto, mas sim unidade unificante ou, como diz Natorp, a relação que para ambos - para o diverso e para a sua unidade - toda a consciência constitui.

Falaremos agora das duas menções seguintes, no final do $\S 13$ e no início

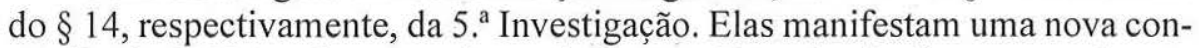
cordância de Husserl com posições de Natorp. Em primeiro lugar, quando este defende que os actos psíquicos não são actividades, mas sim vivências intencionais, devendo-se prescindir de toda uma "mitologia" dos actos enquanto actividades, a qual, em última instância, transfere para a consciência, enquanto centro de relação, o que é próprio de domínios particulares da vida psíquica, como sejam o sentimento ou o esforço. ${ }^{30}$ Em segundo lugar, quando Natorp defende que não se pode, por exemplo, num acto intencional de carácter auditivo, separar a audição do som, do som que é ouvido. Natorp, com efeito, relativamente a este assunto, afirmara no $\S 5$ da Einleitung in die Psychologie,

Idem, Einleitung in die Psychologie nach kritischer Methode, Freiburg, Akademische Verlagsbuchhandlung von J. C. B. Mohr, 1888, p. 58.

28 Idem, ibidem, pp. 25-26.

29 Idem, Allgemeine Psychologie, ed. cit., p. 35.

30 Idem, Einleitung in die Psychologie, ed. cit., p. 18. 
que as expressões: "um som soa para mim" e "eu ouço um som", exprimem o mesmo facto, embora de duas maneiras diferentes: no primeiro caso, considerando o momento da existência objectiva de um conteúdo, no segundo, a sua relação com um sujeito. ${ }^{31}$ Não cabe distinguir realmente um som e a audição desse som (um facto e uma actividade), pois, então, nada impediria que se admitisse ainda uma nova actividade que captaria a audição do som ("eu ouço o som que é ouvido"), e assim sucessivamente. Por outras palavras: na captação de um conteúdo, está já contida, de forma concomitante (Natorp chama-lhe um unbeschreibliche Gegenüber zum Ich), a relação com o Eu que o capta. ${ }^{32}$ Atente-se na passagem seguinte:

"O som soa para mim" e "eu ouço um som" não constituem para mim dois factos, nem dois factos vividos sucessivamente, nem dois factos vividos simultaneamente, mas sim trata-se de um único facto, no qual, em todo o caso, posso distinguir por abstracção os dois conhecidos momentos: a existência do conteúdo e a sua pertença a "mim", quer dizer, ao conteúdo total da minha consciência presente $[\ldots]^{33}$

Husserl, contudo, chama a atenção para a necessidade de não se ficar por esta simples afirmação: retomando o exemplo das análises de Brentano, independentemente das confusões de que possam ter sido vítimas os seus seguidores, dever-se-á transformar a existência de um conteúdo para a consciência - o som ouvido, no nosso exemplo precedente - em tema próprio de análises que digam respeito às possíveis modalidades da sua captação. $\mathrm{Na}$ linguagem de Natorp, ter-se-ia de dizer: para Husserl, nas Investigações Lógicas, a fundação psicológica e subjectiva do conhecimento deverá preceder a sua fundação lógica e objectiva. ${ }^{34}$ (O que, justamente, Natorp contesta, como veremos mais adiante.) A referência, ligeiramente crítica, no final deste mesmo $§ 14$ vai quase no mesmo sentido: Husserl defende que a cada modo de representação pensante corresponde uma diferença na intenção (um som ouvido não é um som recordado, por exemplo) e que, embora a diversidade dos modos de consciência resida nos seus conteúdos, tal não significa que a consciência e os conteúdos devam ser identificados. ${ }^{35}$

31 Idem, ibidem, p. 15. Cf., no mesmo sentido, Allgemeine Psychologie, p. 44.

32 Idem, Allgemeine Psychologie, pp. 43-44. Parece-nos ser óbvio que, neste Gegenüber, o fundamental é, justamente, a sua dimensão unbeschreibliche, ou seja, "impossível de se descrever".

33 Idem, ibidem, p. 44.

34 Idem, ibidem, p. 280.

35 Se interpretamos correctamente a posição de Natorp, dir-se-ia que, para este, a diversidade dos conteúdos institui uma diferença nos conteúdos, mas não entre a consciência deles. À maior ou menor clareza de uma mancha de cor não corresponde, necessariamente, um grau idêntico de clareza na consciência dessas tonalidades. Cf. Allgemeine Psychologie, 
No que se refere às Investigações Lógicas, e, como é óbvio, são sobretudo elas que temos em vista, as diferenças que separam os dois autores não se restringem às que se podem detectar pela leitura das passagens mencionadas. Husserl, como se sabe, projectava uma reorganização completa do texto da 6. ${ }^{a}$ Investigação, que não chegou a levar a cabo por razões que são conhecidas. Se o tivesse feito, ou seja, se o texto publicado em 1921 correspondesse às suas intenções iniciais, teria tido certamente a oportunidade para responder a duas importantes objecções que Natorp lhe colocara na Allgemeine Psychologie, relativas às relações entre a intenção de significação e a intuição de preenchimento. ${ }^{36}$ Natorp, reportando-se a teses defendidas por Husserl nos $\S \S 16$ e seguintes da $6 .^{a}$ Investigação, nega que seja admissível, do ponto de vista da fenomenologia, a possibilidade de um preenchimento definitivo de uma intenção, defendendo que, para a fenomenologia, tal preenchimento apenas deveria poder acontecer gradualmente, por aproximações sucessivas a um ideal que não será nunca atingido. Natorp parece-nos retomar, neste contexto, a distinção kantiana entre o objecto indeterminado, mas determinável, o objecto já determinado e, por fim, a forma da determinação, distinção essa que constitui, também, um elemento central das suas próprias posições gnosiológicas. Assim, o objecto de conhecimento torna-se naquilo que o pensamento procura determinar por meio de um conjunto de relaçõ̃es e não uma coisa-em-si que a elas fosse anterior. A esta luz, a intuição de preenchimento corresponderia, na interpretação de Natorp, à plena determinação do objecto pela forma, algo a que se poderia fazer corresponder a "síntese do reconhecimento no conceito", da $1 .^{a}$ edição da Crítica da Razão Pura, ${ }^{37}$ aquele momento em que, na linguagem de Husserl, a representação encerra o objecto no seu conteúdo fenomenológico. ${ }^{38}$

Este modo de expor a questão poderá parecer demasiado abstracto, mas apenas porque não nos é possível, tendo em atenção os objectivos deste ensaio e o espaço de que dispomos, integrar toda esta problemática no contexto global do pensamento de Natorp. A distinção entre o objecto plenamente determinado (o objecto X, na linguagem de Natorp) e o objecto a determinar pela forma do pensamento (a que Natorp chama o objecto A), que é correlativa do reconhecimento da natureza de todo o acto de pensar como estabelecimento da

p. 49: "das Bewusst-sein des Inhalts, das Bewusst-haben, ist in allen diesen Fällen, der Art nach, als Bewusst-sein, nicht unterschieden."

36 Paul Natorp, Allgemeine Psychologie nach kritischer Methode, pp. 286-287.

37 Kant, Kritik der reinen Vernunf, A 103-110. Kant escrevera em A 105: "conhecemos o objecto quando efectuámos uma unidade sintética na multiplicidade da intuição. Mas aquela unidade é impossível se a intuição não puder ter sido produzida, por meio de uma tal função de síntese, de acordo com uma regra, a qual torna possível a reprodução a priori do múltiplo e um conceito no qual o múltiplo de unifica." Leia-se, contudo, a passagem das Investigações Lógicas citada na nota seguinte para se perceber tudo o que separa Husserl de Kant relativamente a este assunto.

${ }^{38}$ Cf. Husserl, Logische Untersuchungen, Hua, Band XIX/2, pp. 607-608. 
igualdade $\mathrm{A}=\mathrm{X}$, reenvia para um plano genérico de dever-ser (onde a ideia de progresso se constitui como a lei fundamental do pensar) em que às questões de ordem gnosiológica se acrescentam as de ordem pedagógica e social, plano esse que constitui o ponto de unidade em torno do qual se articula a totalidade do pensamento de Natorp. Na realidade, para Natorp - e este facto comprova a especificidade do seu pensamento face ao do fundador da escola de Marburg, Hermann Cohen -, tanto nas ciência físico-matemáticas como nas ciências da cultura uma mesma actividade racional se encontra em acção, que poderíamos caracterizar como sendo a de uma tentativa de plena determinação do objecto pela forma do pensamento.

Contudo, no plano meramente gnosiológico, a que nos ateremos neste ensaio, esta será, talvez, a parte mais débil da crítica de Natorp a Husserl. É certo que é o próprio Husserl que se refere, no $\S 16$ da 6 . $^{\mathrm{a}}$ Investigação Lógica, a uma aproximação progressiva ao objectivo do conhecimento ${ }^{39}$ (o que pareceria, à primeira vista, justificar a referência de Natorp ao mero ideal impossível de alcançar), mas não nos parece que Natorp tenha prestado a devida atenção à subtileza das análises husserlianas da temática da intuição de preenchimento. Por um lado, porque é o próprio Husserl que, ao falar de uma teleologia que seria característica dos actos de preenchimento, distingue graus na plenitude da representação, que vai da mera identificação até ao preenchimento completo. A este propósito, é o próprio Husserl que menciona a possibilidade da plenitude da auto-apresentação, quer como limite ideal, quer, mesmo, como elo final já realizado de uma cadeia de relações de preenchimento de sentido, por assim, dizer ascendente. Ao invés, para Natorp, nunca existe um preenchimento definitivo, ou seja, uma objectivação completa e o objecto encontra-se sempre num certo nível do processo de objectivação. ${ }^{40}$ Por outro lado, o próprio preenchimento, em sentido husserliano, pode assumir formas extremamente diversificadas. Podemos falar, por exemplo, do preenchimento de um acto que visa a demonstração de um determinado teorema e, no entanto, não saímos do plano da manipulação de sinais aos quais o matemático atribui em certo sentido. ${ }^{41}$

39 Idem, ibidem, p. 597.

40 Natorp, Allgemeine Psychologie, ed. cit., p. 286.

41 Sobre este assunto, cf., nomeadamente, o $§ 18$ da 5. ${ }^{a}$ Investigação, Hua, Band XIX/1, pp. 601 e segs. Husserl desenvolverá esta problemática após as Investigações Lógicas e consagrar-lhe-á profundas reflexões no § 49 da Lição de 1907 intitulada Introdução à Lógica e à Teoria do Conhecimento, (Einleitung in die Logik und Erkenntnistheorie, Hua, Band XXIV, Den Haag, Martinus Nijhoff, 1984, pp. 401 e segs.) A tese de Husserl é que todo o acto preenchido é o correlato de um "estado de coisas existencial" - quer dizer, de um ser -, mesmo que o que está em causa seja a solução de uma equação, ou uma função definida de uma certa maneira. A conexão essencial entre os actos, em que as suputações de crença se vêm permanentemente confirmadas, encontra-se na origem de uma "consciência de ser" cada vez mais plenamente realizada. 
Relativamente a este assunto, pensamos mesmo que seria legítimo recorrer-se ao célebre exemplo husserliano do cubo, que, em Ideias I, servirá para ilustrar o processo da visão das essências. ${ }^{42}$ Embora esta última não esteja ainda em questão na $6{ }^{\mathrm{a}}$ Investigação Lógica, Husserl fala de uma síntese total de imaginações ou representações de uma mesma figura que, comparativamente ao que dela podemos saber através de um único acto, representa um crescimento na quantidade do preenchimento, pelo que a imperfeição das apresentações parciais seria relativamente superada na apresentação da totalidade dos seus lados. ${ }^{43}$ (Que se transformaria em apresentação absoluta pelo acrescento dos processos de analogização e simbolização.) O que Natorp, ao que pensamos, gostaria de ter encontrado em Husserl, e que de certa forma se esforça por mostrar que Husserl deveria igualmente ter admitido, seria a sua própria distinção entre o "objecto" do conhecimento em geral - espécie de conceito-limite com o qual o filósofo neo-kantiano indica o termo do processo de objectivação -, e o objecto de níveis particulares de conhecimento, mais ou menos distante de um conhecimento plenamente determinado.

Entre as Investigações Lógicas e as Ideias I há ainda uma referência importante, embora breve, a Paul Natorp. Ela encontra-se nas lições de Göttingen de 1906-07 intituladas Introdução à Lógica e à Teoria do Conhecimento, publicadas no volume XXIV da Husserliana: ${ }^{44}$ Husserl manifesta a sua concordância com Natorp relativamente à unidade entre a lógica e a matemática enquanto constitutivas de uma teoria a priori da ciência, ou seja, de uma doutrina das significações e de uma doutrina do objecto. Nota, contudo, a sua discordância quanto ao modo como Natorp defende aquela unidade, bem como quanto à sua ideia de lógica. Husserl não se alarga demasiado sobre esta última questão, pelo que também não o faremos aqui, contentando-nos com algumas breves referências. ${ }^{45}$

Convém, antes de mais, recordar que, na esteira de Hermann Cohen, Paul Natorp defende que as formas próprias do juízo dependem da lógica do cálculo infinitesimal e não da lógica de Aristóteles. Embora com alguns pontos de contacto com a tese, quase contemporânea, acerca da origem do número, que ficou conhecida, em epistemologia das matemáticas, pela designação de logicismo, a posição dos filósofos de Marburg apresenta algumas

42 Acerca do problema da visão das essências, cf. o $\S 3$ de Ideias I, sobre a relação entre a visão das essências e a intuição de um objecto individual (Hua, Band III, pp. 13-16); sobre a visão perspectivística, como necessidade inscrita na essência de todo objecto percepcionado, cf. o § 41 (Ibidem, pp. 91-95); sobre a relação entre clareza da visão das essências e a clareza da intuição do objecto individual, cf. o § 69 (Ibidem, pp. 159-160).

43 Idem, 5. Investigação, Hua, Band XIX/1, p. 599.

44 Idem, Einleitung in die Logik und Erkenntnistheorie, Hua, Band XXIV, p. 57. Das várias obras de Natorp que Husserl menciona na nota 1 à p. 57 desta obra apenas conseguimos ter acesso à Sozialpedagogik, a que mais atrás fizemos referência; sobre as questões que discutimos acima, cf. todo o $\$ 4$, ed. cit., pp. 35-43.

${ }^{45}$ Cf. Alexis Philonenko, L'École de Marbourg, Paris, Vrin, 1989, pp. 54 e segs. 
particularidades; em primeiro lugar, pelo facto de não estar interessada no número enquanto objecto puramente matemático, mas sim em função da sua aplicação à física. ${ }^{46}$ Pouco tempo depois de Husserl ter proferido a lição que mencionámos, Natorp, em Die logischen Grundlagen der exakten Wissenschaften, obra publicada em 1910, dirá que na lógica do cálculo infinitesimal se exprime a absoluta supremacia do pensamento sobre a realidade (o que é, como sabemos, uma das teses fortes da escola de Marburg) e o facto do real, na medida em que é dotado de inteligibilidade, se encontrar no termo, e não no início, do trabalho do pensamento. ${ }^{47}$ A lógica é, assim, em primeiro lugar, lógica das ciências físico-matemáticas e não uma ciência do objecto em geral, como será para Husserl, confinando por isso, para este, com a ontologia formal. Ou se admitirmos que possa ainda ser, para Natorp, uma ciência do objecto em geral - é provável que ele não recusasse em absoluto esta definição, até porque a noção de um Gegenstand überhaup nos coloca em terreno kantiano -, ela é-o somenté na medida em que o objecto é apenas uma teia de relações estabelecidas pela actividade do pensamento, a variável de uma equação que não se refere a nenhum dado anterior a que pudéssemos chamar realidade efectiva. ${ }^{48}$ Se Husserl, pelo seu lado, se separa da silogística tradicional, tal ficou a dever-se, não a uma reflexão sobre o cálculo, mas sim aos desenvolvimentos, quase seus contemporâneos, da aritmética pura, à teoria das multiplicidades, aos conceitos correlativos de unidade, de quantidade, de conjunto, de elemento de um conjunto, etc..$^{49}$

Todavia, convém prestar aqui atenção ao sentido exacto das palavras de Natorp, sem o que se poderiam cometer certos equívocos que comprometeriam uma correcta interpretação das teses que defende. O que chamámos "supremacia do pensamento sobre a realidade" mais não é do que o processo de fundação objectiva do conhecimento, ou seja, a constituição do objecto enquanto objecto das ciências físico-matemáticas. É somente no termo deste processo de objectivação que se poderá proceder a uma fundação subjectiva, que constitui como que uma espécie de negativo da primeira, mostrando que

46 Esta situação, como se sabe, reflecte-se na interpretação de Kant pela escola de Marburg, em particular por Hermann Cohen. Assim, consideram que a parte principal da Crítica da Razão Pura é a "Analítica dos Princípios" e, em particular, a secção sobre as "Antecipações da Percepção", onde se exprime a possibilidade de construção do objecto, não como grandeza no espaço e no tempo (correlativa da anteposição de uma Estética à Lógica), mas sim como um grau determinado de preenchimento do espaço, ou seja, como grandeza intensiva.

47 Paul Natorp, Die logischen Grundlagen der exakten Wissenschaften, Leipzig und Berlin, Verlag und Druck von G. B. Teubner, 1921 (Zweite Durchgesehene Auflage, Anastatischer Nachdruck, Wiesbaden, Dr. Martin Ständig, oHG, 1969), p. 219

48 Cf. Isabelle Thomas-Fogiel, "Notice" à trad. franc. de Paul Natorp, "Fondation objective et fondation subjective de la connaissance", in Marc de Launay (dir.) Néokantismes et Théorie de la Connaissance, Paris, Vrin, 2000, p. 113. Sobre este assunto, cf. igualmente Mario Porta, "La teoría del número en Natorp y Cassirer", in La Ciencia de los Filósofos, (1996) 199-222, p. 208.

${ }^{49}$ Husserl, Einleitung in die Logik und Erkenntnistheorie, ed. cit., p. 58. 
aquele processo não poderia ter sido levado a cabo sem uma consciência. ${ }^{50}$ Por outras palavras: a primazia pertencerá sempre à fundação objectiva, ou seja, à elucidação de um caso particular pela lei geral de que ele mais não é do que uma instanciação. $\mathrm{O}$ conhecimento, insiste Natorp, deve ser analisado a partir do seu conteúdo objectivo, como uma espécie de equação à resolver, em que uma determinada incógnita é explicada a partir das quantidades já conhecidas. $^{51}$

A resposta anterior, contudo, está longe, para Natorp, de ser suficiente. Não basta afirmar a existência em si do objecto para garantir a validade da fundação objectiva, pois tal existência em si é afirmada por uma subjectividade que coloca aquela existência como algo de independente de si própria. Devemos, ao invés, tomar como nosso ponto de partida, nesta investigação, o ponto de vista do conhecimento e perguntar como pode ele colocar perante si um objecto independente da subjectividade que conhece. Por outras palavras, a objectividade, para o filósofo neo-kantiano, de ponto de partida, ou de postulado implícito, transformou-se no problema que a crítica terá de resolver.

Mas Natorp recusa também que a subjectividade possa ser considerada como uma espécie de objectividade segunda, meramente coordenada à objectividade primeira que seria a dos objectos na sua existência real. O recurso à subjectividade surge, assim, para o filósofo neo-kantiano, sempre que nos referimos a um processo de objectivação já realizado, ao dizermos que ele se pôde realizar e que só uma consciência o poderia ter realizado. Ora, ao que nos parece, esta posição não resulta da constatação de uma qualquer deficiência intrínseca do processo de fundação objectiva, pois, na medida em que esta quer apenas dizer que a validade objectiva é independente da representação de tal ou tal consciência particular, nada há a opor-lhe ou a acrescentar-lhe. Simplesmente, tal não pode significar, apenas, uma afirmação da existência em si do objecto, pois é justamente a determinação desse em si pela consciência, e não a sua ingénua determinação como algo de independente, que está em causa sempre que falamos de conhecimento. ${ }^{52} \mathrm{O}$ projecto das Investigações Lógicas seguia um caminho diferente. Como Husserl afirma, recusando qualquer posição de existência aos objectos visados nos actos de consciência, a fenomenologia toma como objecto os próprios actos e o seu teor de sentido imanente, ${ }^{53}$ mesmo que facto de uma mesma palavra - sensação, percepção, representação, ou outra - poder designar, tanto o acto em si mesmo, como aquilo que é visado nele ${ }^{54}$ torne quase inevitável, para quem permanece na

50 Idem, Allgemeine Psychologie, ed. cit., p. 281.

51 Natorp, “Über objektive und subjektive Begründung der Erkenntnis", ed. cit., p. 144-145.

52 Idem, ibidem, pp. 150-151.

53 Husserl, Logische Untersuchungen, Hua, Band XIX/1, p. 14.

54 Natorp, Allgemeine Psychologie, ed. cit., p. 281. Natorp, contudo, não parece reparar no facto de, para Husserl, o sentido de um acto constituir a própria objectividade por ele visada, ou que, em termos de Frege, o Sinn seja a Bedeutung, ou, pelo menos, que não seja perti- 
atitude natural, uma confusão entre as vivências e os objectos que nelas aparecem.) Natorp tem perfeita consciência de tudo o que o separa da fenomenologia relativamente a este assunto, remetendo, na Allgemeine Psychologie, para as posições expressas por Husserl no $\S 3$ da Introdução às Investigações Lógicas.

\section{Pode a consciência constituir-se como objecto para si mesma?}

A ciência da consciência é, para Natorp, a psicologia. Mas a psicologia não estuda a consciência como algo de análogo à realidade objectiva, ou seja, que pode ser explicado com as mesmas formas categoriais que valem para o conhecimento das coisas, em particular a de substancialidade e a de causalidade. Por outras palavras, a consciência, para Natorp, não é uma "coisa" existente no espaço, sujeita a modificações no decurso do tempo, mas sim, apenas, o facto do "aparecimento", quer dizer, a consciência é o nome para a relação entre os fenómenos percepcionados ou intuídos e o eu que os unifica. ${ }^{55}$ A uma tal relação Natorp chama, como já vimos, Bewusstheit e não Bewusstsein. ${ }^{56} \mathrm{~A}$ tese que defende é que o eu não pode ser objecto, uma vez que é aquilo para o que há objectos. Como diz com ênfase em 1888: o eu não é para si mesmo, ${ }^{57}$ uma vez que, neste caso, seria representável por si, o que implicaria termos de admitir a possibilidade de ele próprio poder representar a sua representação, e assim sucessivamente até ao infinito. Ao eu pode-se circunscrevê-lo tautologicamente, mas não se pode compará-lo com mais nada, nem explicá-lo a partir de mais nada. Face às críticas de Husserl nas Investigações Lógicas, Natorp voltará a este assunto, em 1912, na Allgemeine Psychologie. Aí dirá ${ }^{58}$ que criara, em 1888, o termo Bewusstheit para pôr em evidência que à relação entre o vivido (das Erlebt) e a consciência que experimenta (das erlebende Bewusstsein) não corresponde nenhum conteúdo da consciência, ou seja, precisamente o que Husserl designa pela expressão phänomenologischer Befund no $§ 4$ da $5 .{ }^{a}$ Investigação. ${ }^{59}$ Corresponder-lhe-á, apenas, o que, em linguagem husserliana, chamaremos uma complexão real ${ }^{60}$ das vivências, por outras palavras, a unidade de um enlace.

nente, de um ponto de vista fenomenológico, uma distinção entre os dois nos termos em que Frege a quis fazer.

55 Sobre este assunto, cf. Ernst Cassirer, Die Philosophie der symbolischen Formen, trad. de Ralph Manheim, The Philosophy of Symbolic Forms, New Haven and London, Yale University Press, 1970, $3 .^{\circ}$ vol., p. 52.

56 Paul Natorp, Einleitung in die Psychologie, p. 11.

57 Idem, ibidem, p. 15.

58 Cf., nomeadamente, Allgemeine Psychologie, ed. cit., p. 34.

59 Husserl, Logische Untersuchungen, Hua, Band XIX/1, p. 363.

60 "Real" tem, neste contexto, o sentido que Husserl atribui ao termo alemão reell, por oposição a real. É Reell tudo o que funciona como um componente da esfera intencional. 
Diz Natorp em jeito de conclusão:

Assim, se no conceito de vivência se encontra incluída, quer dizer, quer ser pensada, inquestionavelmente, a identidade efectiva do eu que experimenta e, na verdade, não como uma mera suposição arbitrária, mas sim como um facto absoluto [...], uma identidade que não se esgota na complexão de conteúdo de cada vez delimitada, mas que se alarga, pelo menos segundo a possibilidade, para lá de cada delimitação deste tipo [...], então, esta suposição, como agora reconhecemos, tem, pelo seu lado, a mais profunda e íntima legitimidade. ${ }^{61}$

Pensamos que a psicologia de Natorp, como ciência desta identidade do eu, corresponde, mutatis mutandis, à fenomenologia transcendental de Husserl. Ambas se caracterizam por uma mesma Erkenntnisrichtung, ou seja, na linguagem de Husserl, por uma idêntica Einstellung. ${ }^{62}$ À direcção do interesse cognitivo para o objecto, próprio das ciências físico-matemáticas (ciências da atitude natural, ou ciências mundanas, nas palavras de Husserl), contrapõem ambos os autores um interesse dirigido para o sujeito que conhece. Os dois reconhecem ainda que foi Kant o iniciador das investigações psicológicas ou fenomenológicas que ambos levam a cabo, remetendo, igualmente, para a "Dedução Transcendental das Categorias", na 1. " edição da Crítica da Razão Pura. ${ }^{63}$ (Embora esta remissão, em Husserl, apenas adquira uma forma explicita em 1924, numa conferência sobre Kant que constitui a parte final do $1 .^{\circ}$ volume de Erste Philosophie.) Sobre este assunto, contudo, devemos assinalar uma divergência entre os dois autores que não é destituída de certa importância. ${ }^{64}$ A filosofia transcendental, em Husserl, releva daquela Erkenntnisrichtung que se dirige ao sujeito do conhecimento, ao passo que, para Natorp, ela constitui uma ciência inteiramente objectiva; para este, é à psicologia que caberá inverter a orientação do interesse e focar a actividade subjectiva que acompanha todos os actos objectivantes. ${ }^{65}$

Note-se, também, que para Natorp a distinção entre o plano subjectivo e o plano objectivo não se encontra fixada de uma vez por todas. Chamemos A ao primeiro e $X$ ao segundo. Qualquer afirmação do tipo "A tem um X" (ou representa um $\mathrm{X}$, ou visa um $\mathrm{X}$ como objecto) referir-se-á sempre a um certo estádio do processo de objectivação. Aqui, Natorp parece-nos muito próximo do que Hegel, por exemplo, defenderá na "Prefácio" à Fenomeno-

61 Paul Natorp, Allgemeine Psychologie, ed. cit., p. 38.

${ }^{62}$ As duas palavras alemãs podem ser satisfatoriamente traduzidas para português por, respectivamente, "orientação de conhecimento" e "atitude".

${ }^{63}$ Iso Kern, op. cit., pp. 192 e 329.

64 Idem, ibidem, p. 328.

${ }^{65}$ Cf., nomeadamente, Ernst Cassirer, "Erkenntnistheorie nebst den Grenzfragen der Logik", in Gesammelte Werke (Hamburger Ausgabe), Darmstadt, Wissenschaftliche Buchgesellschaft, 2001, pp. 139-200, p. 198. 
logia do Espírito. ${ }^{66} \mathrm{O}$ elemento objectivo do conhecimento é apenas objectivo para um dado momento do processo de objectivação. ${ }^{67}$ Assim, por exemplo, o que pode parecer objectivo na percepção de uma certa tonalidade de vermelho ou de verde torna-se subjectivo quando compreendemos a cor como um certo tipo de ondas luminosas com um determinado comprimento.

Quanto ao problema da possibilidade em transformar a consciência em tema de estudo, a discussão, que referimos anteriormente, acerca da pertinência em distinguir um som que se ouve, da audição desse mesmo som, pode, mais uma vez, ser-nos de algum auxílio. Natorp introduz esta discussão, em 1888, sem referir a posição de Franz Brentano sobre o mesmo assunto, alguns anos antes, na sua Psicologia de um Ponto de Vista Empírico, mas estamos em crer que Natorp, não só conhecia a posição de Brentano, como também é a ela que toma por alvo no referido ensaio. ${ }^{68} \mathrm{Com}$ efeito, não só Brentano defendera a necessidade de efectuar a referida distinção, como acrescentara ainda uma terceira, a que chamara "percepção de si mesmo", ou seja, representação de si enquanto alguém que representa qualquer coisa (e que, no nosso exemplo anterior, é, justamente, o som). Percebe-se a razão daquela tripla distinção brentaniana. Trata-se, para Brentano, de evitar qualquer tipo de idealismo gnosiológico. Se na audição de um som não estivesse contida a referência a um som real ou efectivo, a representação de si mesmo enquanto alguém que ouve e a representação do som seriam a representação de um mesmo objecto. ${ }^{69}$

Mas, para obviar à dificuldade que consistiria em postular uma representação inconsciente como último termo desta "representação de uma representação" - pois, para Brentano, uma representação inconsciente é uma contradictio in adjecto -, há, para o filósofo vienense, apenas uma solução: admitir apenas um fenómeno psíquico, mas dois objectos diferentes, a saber, no exemplo dado mais acima, o som a que o fenómeno psíquico se refere, ou "objecto primeiro", e o próprio fenómeno enquanto "objecto segundo".70 A este único fenómeno psíquico chama Brentano, também, acto. Ora, em nossa opinião, a fenomenologia de Husserl é a ciência destes actos brentanianos, ou "objectos segundos", liberta de qualquer mitologia da actividade psíquica subjacente ao que aparece nesses actos (e, por conseguinte, de todo o "mentalismo", corolário necessário daquela mitologia ${ }^{71}$ ) bem como de toda a

66 Proximidade relativamente a Hegel, mas, também, relativamente a Platão, criticando a tese que este, no Teeteto, pela boca de Sócrates, atribui a Protágoras: "não podemos experimentar algo que não seja, podemos apenas acreditar naquilo que experimentamos, e isso é sempre verdadeiro." (167 a) A ser assim, seria necessário admitir-se uma fundação subjectiva do conhecimento que não tivesse a sua contrapartida numa fundação objectiva. Natorp, Allgemeine Psychologie, pp. 47-48.

68 Cf. Franz Brentano, Psychologie vom empirischen Standpunkt, Hamburg, Félix Meiner, 1924, Band I, pp, 170 e segs.

69 Franz Brentano, Ibidem, p. 173.

70 Sobre este assunto, cf. Lucie Gilson, op. cit., pp. 52 e segs.

71 Jocelyn Benoît, op. cit., p. 293. 
problemática da distinção entre o físico e o psíquico, que fora, como sabemos, o motivo inicial da teoria da intencionalidade de Brentano.

Natorp reconhece que a fenomenologia husserliana, após as Investigações Lógicas, se encaminhou no sentido da constituição de uma ciência descritiva dos actos, aproximando-se, nessa medida, do que chama o "platonismo da primeira fase", ou seja, o das "essências em repouso". ${ }^{72} \mathrm{E}$ embora a avaliação que Natorp faz da evolução do pensamento de Husserl, após a publicação da obra de 1900-01, ultrapasse já os objectivos do presente ensaio, permitimo-nos, ainda assim, uma pequena referência ao que a Allgemeine Psychologie afirma sobre a posição de Filosofia como Ciência de Rigor. ${ }^{73} \mathrm{Em}$ 1911, afirma Natorp, Husserl defende uma rigoroșa separação entre, por um lado, tudo o que diga respeito à exposição científica dos fenómenos psíquicos e, por outro, à objectivação no sentido das ciências da natureza; desta forma, não cabe no âmbito do psíquico a distinção entre o ser e o fenómeno, pois o psíquico já não é definido como um ser através do qual apareçam quaisquer fenómenos que se ocultem por detrás. A natureza do psíquico não seria mais, então, objecto de uma experiência no sentido físico do termo - uma vez que os fenómenos psíquicos também não são objectos -, mas sim, unicamente, de uma vivência.

72 Ibidem, p. 288 e 289. Natorp tem em vista a posição de Husserl expressa em Philosophie als strenge Wissenschaft, publicado em 1911 na revista Logos. No horizonte da crítica de Natorp encontra-se a sua própria interpretação de Platão, em particular do Teeteto e do Sofista, que seria aqui deslocado estar a desenvolver.

73 Filosofia como Ciencia de Rigor parece ter despertado um particular interesse entre autores ligados às diversas escolas neo-kantianas. Pouco antes de falecer prematuramente, em 1915, Emil Lask, que estudara a fundo o Logos-Aufsatz, reagirá com vigor à contraposição husserliana entre fillosofia científica e concepção do mundo. (Sobre este assunto, veja-se a carta de Lask a Husserl, de 29.03.1911, em Edmund Husserl, Briefwechsel, Band V, ed. cit., pp. 32-33. Cf., igualmente, Lask, Zum System der Philosophie, in Gesammelte Schriften, Band III, Tübingen, J. C. B. Mohr (Paul Siebeck), 1924, pp. 251-252.) Lask defende que a filosofia constitui justamente, aquela actividade do entendimento que se caracteriza por esclarecer a vida irreflectida, que lhe fornece o material para poder pensar. Este material, no entanto, irredutível, pela sua própria natureza, à forma lógica do pensar, permanece como o fundo caótico e insondável que a luz do entendimento nunca penetrará por completo. (Lask elaborou uma teoria da matéria e do caos cujas raízes remontam, em última instância, a Plotino, de que era um profundo conhecedor.) Somente a título de curiosidade, registou-se, também, que um antigo aluno de Lask, o filósofo húngaro Georgy Lukács, pouco depois da sua adesão ao marxismo, aproximara a posição de Lask e de Husserl. (Cf. Georgy Lukács, Geschichte und Klassenbewusstsein, trad. cast., Historia y Consciencia de Clase, Barcelona, Ediciones Grijalbo, 1975, p. 163.) Lukács defende que a posição de Lask significa que ao entendimento, através das formas lógicas de que se serve, compete somente a função de ordenar um material insistematizável, do mesmo modo que, para Husserl, o campo da lógica constitui uma espécie de facticidade de nível superior, desligada, em virtude da redução fenomenológica, da matéria que constitui o seu campo de aplicação, e apenas passível'de descrever quanto ao seu modo de operar. Heinrich Rickert, o mestre de Lask (em carta a Husserl, de 28.06.1911. Cf. Briefwechsel, Band V, ed. cit. pp. 170-171), relativizará também aquela oposição husserliana, afirmando não lhe parecer impossível penetrar com o auxílio da ciência nas questões últimas sobre o sentido da vida, que têm constituido o terreno próprio da filosofia ideológica. 
Irrompe, então, com perfeita legitimidade, aquela pretensão da fenomenologia em ser uma pura ciência descritiva das vivências, uma vez que tal descrição não incide sobre os fenómenos psíquicos na sua existência efectiva, mas sim neles enquanto constituem, apenas, a expressão das essências e de relações entre as essências. Como afirma Natorp, a filosofia é uma Wesenslehre e não uma Daseinslehre. ${ }^{74}$ Faltou a Husserl, contudo, ainda na opinião de Natorp, o equivalente ao que fora, em Platão, o movimento das ideias, ou seja, o reconhecimento de que o conhecimento é um processo de "limitação do ilimitado"; a Husserl terá escapado, assim, a descoberta do momento genético, que Platão, na sua segunda fase, pusera em evidência. Um som ouvido, por exemplo, seria, então, a simples vivência de um som já identificado no seu eidos de som. Curiosamente, Natorp parece-nos dirigir a Husserl as mesmas críticas que são dirigidas ao próprio Natorp por alguns intérpretes que são partidários das posições fenomenológicas. Abordaremos este assunto na nossa Conclusão, onde procuraremos determinar o lugar exacto das teses de cada um dos autores relativamente às do outro.

\section{Conclusão}

Se considerarmos a fenomenologia como a ciência dos actos - e pensamos que sem a psicologia de Natorp a fenomenologia talvez não se tivesse constituído do modo como o fez -, podemos ver que há, ainda assim, duas coisas que a separam dela. Em primeiro lugar, a relação que mantém com as disciplinas filosóficas particulares e com as ciências ditas "mundanas". Numa carta a Natorp, de 18.03.1909, Husserl situa o ponto de partida da fenomenologia no que classifica como "phänomenologische(s) Unten"; por outras palavras, a fenomenologia é a ciência constitutiva da objectividade dos objectos, a partir dos níveis inferiores da actividade intencional. Alguns anos mais tarde, no projecto de Prefácio à 2. ${ }^{a}$ edição das Investigações Lógicas, Husserl voltará a esta questão, que o separa, como ele próprio aí afirma, dos idealistas. A fenomenologia nada tem a ver com "construções transcendentais", ${ }^{75}$ mas sim com actos da consciência, com intenções, com o preenchimento das visadas intencionais, e coisas semelhantes. Não admira, reconhece Husserl, que, aos olhos dos idealistas, possa ter recaído no psicologismo, ${ }^{76}$ no $2 .{ }^{\circ}$ Tomo das Investiga-

74 Natorp, ibidem, p. 288.

75 Cf. "Entwurf einer Vorrede, Erstes Fragment", in Logische Untersuchungen, Ergänzungsband, Erster Teil, ed. cit., p. 279.

76 Restará, obviamente, saber se Husserl entendeu correctamente o sentido deste psicologismo, de que Natorp fala na obra de 1912. Pois Natorp não o acusa de ter regredido para uma posição que os Prolegómenos tinham já ultrapassado, mas sim de ocultar, nas suas análises descritivas - mas, efectivamente, psicológicas, no sentido que Natorp atribuía a este termo -, a necessidade de uma fundamentação subjectiva do conhecimento. Cf. Allgemeine Psychologie, p. 280. 
ções Lógicas, que tão acerbamente criticara nos Prolegómenos. Para Natorp, ao invés, a psicologia, enquanto ciência que reconstrói os actos subjectivos que originaram essas objectividades de nível superior que são as configurações das ciências, supõe os níveis superiores de actividade da consciência. Em qualquer caso, não seria difícil encontrar, em Natorp, um equivalente àquele phänomenologisches Unten, de que falava Husserl, nos pretensos sinnliche Elementarinhalte de que se ocupa a Allgemeine Psychologie. ${ }^{77}$ A diferença entre uma sensação visual e uma sensação auditiva, por exemplo, ou entre sensações correspondentes a tonalidades diferentes de uma mesma cor, é, em primeiro lugar, obviamente, uma diferença entre conteúdos diferentes, e não uma diferença que diga respeito à consciência dessas sensações. Só que, para Natorp, mesmo em tais conteúdos elementares sensíveis é já manifesta a unidade da consciência, com a ressalva de que a encontramos, não na qualidade de um elemento que se acrescentasse a esses conteúdos, mas precisamente no mesmo plano em que eles são, justamente, tais conteúdos, estruturando-se e articulando-se do modo em que o fazem.

Mas, mesmo que nos fosse possível alguém conceder aquela equivalência que mais acima referimos, pensamos que tal, por si só, não seria suficiente para que pudéssemos pôr totalmente de acordo o pensamento dos nossos dois autores relativamente a este assunto. Àquele phänomenologisches Unten husserliano corresponderão aos graus mais baixos da consciência intencional, o momento em que a actividade sintética da consciência como que tende para um limite inferior $=0$, e em que uma pura hylé como que se daria sem morphé. Tal é impensável para Natorp. Para o filósofo de Marburg, ${ }^{78}$ o nível inferior do conhecimento objectivo é, num sentido particular, justamente o que manifesta o mais elevado índice de subjectividade, na medida em que as funções que desempenham o trabalho de objectivação - ou seja, as categorias kantianas de quantidade, qualidade, relação e modalidade, bem como a sua realização de acordo com os princípios do entendimento puro - ainda mal iniciaram o processo de constituição do objecto. ${ }^{79}$

Daqui decorre, muito naturalmente, uma segunda diferença entre os dois autores, que diz respeito à determinação, por ambos, tanto da psicologia, como da fenomenologia, como sendo "filosofia primeira" ${ }^{80}$ Para Husserl, a fenomenologia é prima philosophia, no sentido quase cartesiano do termo, na medida em que se desenvolve em completa independência relativamente às ciências mundanas, por Einklammerung do tema próprio de cada uma delas e do valor objectivo dos seus resultados. Para Natorp, a prima philosophia, que a "psi-

77 Allgemeine Psychologie, pp. 47 e segs.

78 Ibidem, p. 69.

79 Refira-se, ainda, que, para Husserl, não são tais categorias, pelo menos na sua acepção kantiana, que levam a cabo este processo. Cf., na 6. Investigação Lógica, § 4, a análise da proposição "um melro levantou voo", Hua, Band XIX/2, pp. 550 e segs. 
cologia segundo o método crítico" deverá ser, supõe todas as outras ciências como seu ponto de partida, aparecendo, de certa forma, só depois delas. A oposição entre os dois pensadores, contudo, não será talvez completa, como, aliás, nota Iso Kern na obra que citámos em nota, ${ }^{81}$ embora não, em nosso entender, exactamente nos termos em que a questão é por ele apresentada. Com efeito, Husserl nota que a fenomenologia deverá ultrapassar o seu estádio meramente descritivo e elevar-se a uma verdadeira fenomenologia da razão, constituindo, não apenas uma ontologia formal enquanto região dos objectos em geral, mas também as diversas ontologias das regiões supremas da objectividade. Neste nível, o trabalho do fenomenólogo encontrará, certamente, as ontologias ingenuamente constituídas - ou seja, que partem da atitude natural-, em ordem a um estabelecimento dos seus conceitos fundamentais. Tal não impede, contudo, que o fenomenólogo, ao contrário do filósofo neo-kantiano, inicie seu trabalho a partir da esfera da intuição imediata. O acesso a esta esfera imediata supõe, para Husserl, a Einklammerung de todas as ontologias regionais, de todas as decisões metafísicas sobre o ser - ou sobre o ser tal (so-sein) - deste ou daquele domínio de objectividade, de todas as sedimentações de sentido provenientes dos processos de objectivação que têm a sua sede no trabalho das diversas ciências positivas.

Encontramos aqui, provavelmente, a diferença que muitos intérpretes consideram como sendo a mais radical entre os nossos dois pensadores; possivelmente, também, aquela que para muitos mais radicalmente separa a fenomenologia e o neo-kantismo. ${ }^{82}$ Mas uma divergência quanto ao ponto de partida teria de determinar, necessariamente, uma divergência quanto ao sentido da investigação; a consciência, para Husserl, não é apenas uma relação uniforme e indiferenciada a um conteúdo, pois articula-se em distintos "caracteres de acto", que são imanentes às vivências intencionais e determinam o modo da relação com o objecto. ${ }^{83}$ A eliminação de qualquer tipo de transcendência, por um lado, e a redução ao que se dá de um modo puramente fenomenológico, por outro, farão aparecer o que, na terminologia de Ideias I, Husserl chamará a consciência como resíduo. ${ }^{84}$ Para Natorp, tudo se passa de maneira

81 Idem, Ibidem, p. 333. Kern remete, entre outros textos de Husserl, para Erster Philosophie, in Husserliana, Band VII, 187-188. É este texto que temos em mente nas afirmações que produzimos a seguir.

82 Cf. Iso Kern, op. cit., p. 337.

83 Cf. René Schérer, La Phénoménologie des "Investigations Logiques" de Husserl, trad. cast., La Fenomenologia de las "Investigaciones Lógicas” de Husserl, Madrid, Editorial Gredos, 1969 , p. 255. De qualquer modo, fica-nos a dúvida sobre se esta crítica, por válida que possa ser se tivermos em conta a globalidade do movimento neo-kantiano, não será injusta para com Paul Natorp. Pelo menos como declaração de princípio, podemos ler na Allgemeine Psychologie que a relação do eu com o conteúdo da consciência não é desprovido de diferenças e que o modo como cada conteúdo se insere na unidade das vivências é, em cada caso, distinto. (Op. cit., p. 34.)

${ }^{84}$ Cf., igualmente, Husserl, Logische Untersuchungen, Hua, Band XIX/1, p. 368, nota. 
diferente. Trata-se apenas de descrever a correspondência entre a unidades objectivas reais e a subjectividade primitiva (que constitui aquelas por intermédio da unidade da lei ${ }^{85}$ ), sem que seja legítimo falar-se de um privilégio do caminho que se dirige para o sujeito relativamente àquele que se dirige para o objecto. Por outras palavras: para Natorp, a consciência nunca se dá, por isso não se descreve, antes se reconstrói a partir do processo de objectivação, de um modo análogo ao realizado por Kant na "Dedução Transcendental das Categorias". Mas isto levar-nos-ia já para uma outra questão: o da crítica de Natorp às Ideias $I$, o que sai fora do quadro de problemas a que nos quisemos restringir.

\section{ABSTRACT}

The paper offers a survey of the debate between Husserl and Paul Natorp that followed the publication, by the former, of Logical Investigations, in 1900-1901. Beyond a general agreement on the nature of psychologism and the ways to struggle against it, Husserl and Natorp disagreed, at the time, on the nature and function of consciousness. As Natorp defended, since his Introduction to Psychology of 1888, that the objective contents of consciousness are distinct from the I as the subjective (and unobjectifiable) point of reference of them all, Husserl remarks the inner contradiction of these argument; as long as philosophy pretends to speak of such an I it has to be treated as an object, albeit of a special kind. In the Logical Investigations, nevertheless, Husserl stresses that it is not even necessary to admit the existence of such an I to explain the acts of consciousness. However, and that is the central theme of the paper, the later evolution of Husserl's thought and finally his «transcendental turn» can only be fully comprehensible from the admission of a strong influence of the previous criticized thesis of Natorp. 
